\title{
Wanneer klop jy jou pyp op jou velskoen uit? Oor stories en kultuurkritiek
}

\author{
Ernst Wolff \\ Tydelik-deeltydse dosent: Departement Godsdiens- en Sendingwetenskap \\ Universiteit van Pretoria
}

\begin{abstract}
At what moment do you knock out your pipe on your velskoen? On stories and cultural criticism

This essay proposes a frame of reference in which the culture critical introspection of a community can be understood. A critical exposition of elements of the philosophies of Jeismann, Kuhn, Gadamer and Lyotard is developed with reference to their value for a narratological perspective. The author proposes a narrative understanding of a community and its members, their documents and the relation between community, members and documents. Two elements in relation to which stories of any community in South Africa could be read - racism and nationalism - are also examined.
\end{abstract}

When people ask me - as they often do, how it is that I can tell the best stories of anybody in the Transvaal (Oom Schalk Lourens said, modestly), then I explain to them that I just learn through observing the way that the world has with men and women. When I say this they nod their heads wisely, and say that they understand, and I nod my head wisely also, and that seems to satisfy them. But the thing I say to them is a lie, of course. For it is not the story that counts. What matters is the way you tell it. The important thing is to know just at what moment you must knock out your pipe on your veldskoen, and at what stage of the story you must start talking about the School Committee at Drogevlei. Another necessary thing is to know what part of the story to leave out.

(Bosman 1984:47) 


\section{INLEIDING}

In hierdie opstel wil ek 'n bydrae maak tot die terreinverkenning oor wat die beoefening van kultuurkritiek in 'n bepaalde gemeenskap behels. My uitgangspunt is dat enige kultuurkritiek wat beoefen word, by ' $n$ kultuurkritiese selfbekyking moet begin. As 'n kerk dan kultuurkritiek wil beoefen, moet daar eers krities gekyk word of daar enige filosofieë, wêreldbeskouings, ideologieë, utopieë of dwaalleringe is wat negatief op die geloofslewe van die lidmate en die werk van daardie kerk inwerk, wat in die kerk self geïdentifiseer kan word. As so iets gevind word, wat op gereelde grondslag bedryf word, sal dit die beoefening van kultuurkritiek wat na buite gerig is, ' $n$ misplaaste en arrogante onderneming maak.

Onder kultuurkritiek verstaan ek 'n filosofies-menswetenskaplike bestudering van dinge in ons sosiale leefwêreld om tot 'n samehangende verstaan daarvan te kom met die oog daarop om etiese vergrype uit te wys. Aangesien kultuurkritiek self ook 'n sosiale verskynsel is, bied dit sigself aan om eties beoordeel te word. As etiese beoordeling maak dit aanspraak op morele high ground en daarom is dit van groot belang om die posisie self voortdurend te ondersoek. Dit geld nie net vir my posisie in die kerk nie, maar ook vir my indiwidueel. Kultuurkritiek is ' $n$ aanbod van die filosoof van hom- of haarself aan die gemeenskap. Die filosoof knoop hom- of haarself in ' $n$ mate aan die gemeenskap op hierdie manier, maar ook aan die hoop dat daar regstelling sal kom of ten minste dat die waarheid gehoor sal word.

\section{DIE KERK, STORIES EN FILOSOFIE}

Die kerk is 'n gemeenskap van mense wat vir mekaar en vir ander mense stories vertel. Dit is stories oor God en die mense.

Daar is verskillende maniere waarop stories oorvertel word: vir mekaar na aandete, vir ' $n$ vriend in die hospitaal, vir nuuskieriges wat ons uitvra, in die erediens, en so meer. Ons vertel ook ons stories vir mense wat krities nadink, byvoorbeeld by universiteite. Die teologie-fakulteit en studiegroepe van die kerk spesialiseer daarin om uit te vind hoe om stories vir mense in verskillende kontekste te vertel, op só 'n manier dat die mees goedgelowige en die mees skeptiese geeste ook na die storie sal kan luister. Aan die fakulteit en in die kerk word dinge gedoen wat vertellers help om die storie meer 
geloofwaardig (soos wat dit deur die kerk of individue ingesien word) oor te vertel navorsing en onderrig, sakramente en sopkombuise, huisbesoek en begrafnis, ensovoorts.

Wat is ' $n$ storie? 'n Storie is 'n kreatiewe bymekaarbring van karakters in tyd en ruimte deur die ontvouing van 'n intrige. Deur die manier waarop die storie oorvertel word, skyn daar ' $n$ vyfde element deur of word ' $n$ vyfde element beoefen: ek noem dit die leefwêreld van die skrywer/verteller en die boodskap (implisiet of eksplisiet) en dit wat mense soms die ideologie van 'n teks noem, maak deel hiervan uit. Voordat ek die leefwêreld verder uiteensit, kom ek gee 'n inleidende voorbeeld: Rooikappie en die wolf is 'n storie sonder 'n eksplisiete boodskap. Maar deur die spesifieke gebruik van karakters (wolf: plat karakter, antagonis; ma: dekor; Rooikappie: karakterontwikkeling, protagonis), ruimte (twee bospaadjies; ma se huis/ouma se huis), tyd (Rooikappie kom ná die wolf by ouma) en intrige (die wolf wat Rooikappie om die bos lei; die wolf wat sterf; Rooikappie se noue ontkoming), word die luisteraar begelei om met Rooikappie tot die insig te kom dat mens nie met die slegte ou wolf moet praat nie. Dit is die implisiete boodskap. Daar is egter nog meer aan die storie, byvoorbeeld die bekendheid met die ou wolf as die beliggaming van die bose. Ons ken hom uit die stories van die drie varkies en die wolf, die sewe skapies en die wolf, en ander. Die storie van Rooikappie en die wolf resoneer dus met ander stories. Dit resoneer ook met die wêreld buite die storie, waarin dit ingebed is: die stories van die lewens van die luisteraar en die verteller. Die skrywer van hierdie opstel kan nie bogenoemde sprokies vertel sonder dat 'n luisteraar sal dink dat hy dalk op homself aanspeel nie. Maar breër nog - die storie spruit voort uit ons bekendheid met die gevare van die lewe, ons wens om mense daarteen te beskerm, en die ideaal dat die luisteraar op ' $n$ manier deur die storie georiënteer sal word.

'n Kultuurkritikus is iemand vir wie dit as vreemd opval dat dit juis die wolf is wat elke keer die vark in die verhaal is en tot 'n verstaan probeer kom waarom dit die geval is. In wat volg, gaan ek probeer om 'n paar belangrike fasette van 'n kultuurkritiese selfbekyking van die kerk uit te lig. Die fasette wat ek aanbied, is toegespits op die vraag van die ideologie van kerklike verhale soos dit veral in die dokumente van 'n kerk nagespeur kan word. Omdat die saak van die verhouding tussen verskillende kerke en die staat en die saak van rassisme in kerke so in die brandpunt van kontemporêre 
debatte staan, beoog my studie om behulsaam te wees om hierdie sake in kerklike dokumente te ondersoek.

\section{DIE LEEFWÊRELD VAN'N STORIE/VERTELLER}

\subsection{Oor die rol van stories in mense se lewens}

Maar ek moet nou eers antwoord op 'n beswaar dat ek al die kerk se uitsprake tot stories reduseer. Ek beweer geensins dat alle kerklike dokumente in narratiewe genres is nie. Wat ek wel betoog, is dat die uitsprake soms wel verhalend is (by uitnemendheid geskiedenis in verskillende vorme);

- dat verhaalelemente van verskillende verhale in nie-narratiewe tekste voorkom;

- dat daar in dokumente uitsprake gemaak word wat self reeds historiese gebeurtenisse is;

- dat hierdie teksgebeurtenisse ingebed is in die verskillende verhale wat deur 'n skrywer geleef word;

- dat die uitsprake vir hulle legitimiteitsaansprake afhanklik is van hierdie ingebedheid in lewens- en ander verhale;

- dat die uitsprake op hulle beurt weer eksplisiet of implisiet verwys na die leefwêreld en dit legitimeer.

Om hierdie punt duideliker te maak, moet ek die leefwêreld vanuit 'n paar verskillende perspektiewe verder nuanseer. Maar voordat ek dit doen moet ek eers nog veld skoonmaak deur iets te sê oor (1) die aard en (2) waarde van geskiedenis en oor (3) die gemeenskap waaruit dokumente kom.

(1) Ek beskou geskiedenis ook as 'n tipe verhaal. Die skerp onderskeid tussen ware geskiedenis en valse stories het in ons tyd onder skoot gekom. Aan die een kant word die kennis en wysheid van stories ingesien en, aan die ander kant, word die subjektiwiteit, konteksgebondenheid en ideologie van die geskiedskrywer ingesien. Ek vertrek hier van die oortuiging dat stories op dieselfde of op 'n vergelykbare manier as geskiedenis werk. Geskiedenis maak 'n groot deel uit van die stories waarvan ek praat. 
Verder het ons ook te doen met stories, soos 'n persoon se eie verstaan van sy of haar outobiografie, wat nòg fiksie nòg wetenskap is.

Soos ek reeds gesê het, is my studie gerig op 'n lesing van kerklike dokumente wat daarop aanspraak maak dat dit oop is vir wetenskaplike en filosofiese evaluering. Dit het met ander woorde 'n geldigheids- of waarheidspretensie. Die stories wat in sulke dokumente vertel word, of die tipe stories waarop die inhoud of beoefening van ander genres berus, hoef natuurlik nie regtig waar te wees nie, maar moet as geldig aangebied en opgeneem word. Geldig waarvoor? Waarom vertel mense stories? Dit bring my by die waarde van geskiedenis.

(2) Om die vraag te beantwoord behelp ek my van Jeismann (1985:13-17) se betoog oor geskiedenis, naamlik dat dit 'n drieledige funksie vir ' $n$ mens se selfverstaan in die hede vervul:

\footnotetext{
- legitimasie van aansprake of optrede;

- identiteitstigting;

- lewensoriëntasie.
}

In al drie hierdie funksies bly die mens deur die geskiedenis op die toekoms gerig. Voorts wil ek daarop wys dat elke mens in verskillende stories staan: die storie van my lewe, die storie van wat ek as my volk beskou, die storie van my professie, die storie van my geloofsgemeenskap, of wat ookal. Baie van die stories maak deel uit van groter stories of sny deur ander stories. Baie stories is groepsbesit. Soms verkeer stories in konflik met mekaar en ander kere vul hulle mekaar aan. Elkeen hiervan dra tot 'n mindere of ' $n$ meerdere mate by tot die rol van die drie funksies wat Jeismann bespreek.

(3) Die kerklike dokumente wat hier ter sprake is, ontstaan in 'n relatief geslote gemeenskap en dit is nie vergesog om die skrywers van die dokumente te sien as lede van 'n akademiese/wetenskaplike gemeenskap nie. In die geval van die Hervormde Kerk het al die samestellers van dokumente opleiding in teologie by die Universiteit van Pretoria ontvang en die meeste wat nagraadse studies gedoen het, het dit ook aan dié universiteit voltooi. Dieselfde beleidsdokumente word onderskryf. Daarbenewens beoefen die meeste lede 'n aktiewe verbintenis tot die Afrikaner-volk (my kwalifikasie geld meer in 
vroeëre dekades) en almal behoort tot dieselfde geloofsgemeenskap. Al hierdie feite sorg vir 'n klomp gedeelde waardes in die gemeenskap, van waaruit die dokumente ontstaan.

Dan is dit ook algemeen bekend dat wetenskaplike uitsprake hulleself nie kan begrond nie, maar dat dit gedoen moet word deur 'n gemeenskap wat aan die wetenskaplike uitsprake voorafgaan. Maar dit is waarop ek nou verder wil ingaan: ek wil probeer om die werking van veelvuldige lewens-oriënterende verhale verder te belig. Dit bring ons eerstens uit by Thomas Kuhn.

\subsection{Paradigmas}

In aansluiting by wat ek sopas gesê het, kan ek Kuhn se idee van 'n paradigma bespreek. Ek is wel bewus daarvan dat die toepassing van sy paradigma-teorie op geesteswetenskappe nie 'n voor die hand liggende saak is nie, en des te meer die toepassing daarvan op sosiale verskynsels. Ek meen egter dat die wyse waarop ek dit gebruik in die konteks van my ander uiteensettings daaraan geloofwaardigheid sal verleen.

Kuhn bied in sy Postscript [1969] 'n aanvanklike definisie van 'n paradigma as “.... the entire constellation of beliefs, values, techniques, and so on shared by the members af a given community" (Kuhn [1962] 1970:175). Voorts kommentarieer hy dit voorlopig as volg:

- Paradigmas is gerig op probleem-oplossing in soverre as wat die lede van die gemeenskap die funderings daarvan as vanselfsprekend aanvaar. "A paradigm governs, in the first instance, not a subject matter, but rather a group of practitioners." ([1962] 1970:180). Op hierdie gemeenskap is die wetenskap gebaseer (sowel in normale fases as tydens wetenskapsrewolusies).

- Die mate waarin instemming van die gemeenskap se lede tot die paradigma vereis word, hang af van wat die gemeenskap doen. Daar word met ander woorde 'n mate van dissensus op sekere elemente van die paradigma getolereer.

- Maar ek wil eintlik uitkom by Kuhn se uiteensetting van paradigma in die breèr sin, in die sosiologiese sin. 'n Paradigma/stel paradigmas is dit wat in 'n professionele gemeenskap 'n volheid van kommunikasie en eenstemmigheid in oordele tot gevolg het. Kuhn noem dit ook 'n "disciplinary matrix", omdat dit gemeen- 
skaplike besit is van die gemeenskap en omdat dit opgebou is uit geordende elemente van verskillende aard. Hy noem vier sulke elemente:

- $\quad$ Simboliese veralgemenings.

- Metafisiese beskouings - dit is gedeelde verbondenheid (commitment) aan sekere basiese ontologiese oortuigings en heuristiese modelle.

- Waardes, byvoorbeeld dat die wetenskap nuttig moet wees vir die gemeenskap let op Kuhn se belangrike kwalifikasie van gedeelde waardes as element van paradigmas: ".... though values are widely shared by scientists and though commitment to them is both deep and constitutive of science, the application of values is sometimes considerably affected by the features of individual personality and biography that differentiate the members of the group" (1970 [1962]:185). Wat lede van die gemeenskap laat verskil in die toepassing van gedeelde lojaliteite is nie in die eerste plek ' $n$ prioriteit om die paradigma of wetenskapsbeoefening nie, maar lojaliteit aan die lid self of aan ander mense (dit wil sê: ander paradigmas of lewens), wat die wetenskaplike se lewensverhaal uitmaak.

- Lojaliteit teenoor gedeelde voorbeeld-oplossings (exemplars). In die wetenskap, byvoorbeeld, die illustrerende oplossings van modelprobleme in handboeke. Dit is paradigmas in die enger sin van die woord.

By hierdie uiteensetting wil ek voeg dat 'n persoon aan meer as een paradigma kan behoort. As dit my geoorloof is om paradigma in hierdie baie uitgebreide sin te kan gebruik en as dit nie die basiese eienskappe en werking van paradigmas verander nie, dan kan ons aan paradigmas dink as oorvleuelende stories van lojaliteite, van probleemhantering, van verstaan, van legitimerings, ensovoorts.

\subsection{Metastories}

Dit is seker nie 'n verrassing dat my bespreking in gesprek tree met Lyotard se boek $L a$ Condition Postmoderne (1979) nie. Lyotard se sentrale oogmerk is om aan te toon dat die vorms waarin kennis aangebied word deur metastories (wat 'n filosofie van geskiedenis impliseer) gelegitimeer word; dieselfde metastories legitimeer kennis en geregtigheid 
en die instellings waardeur albei in 'n bepaalde konteks bevorder word'. Lyotard se verslag sentreer om die praktyk van taal-beoefening (1979:20-21). Wat hy aantoon is dat

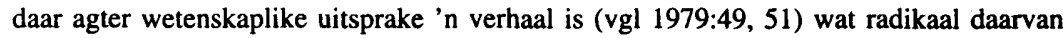
verskil ten opsigte van sy performatiewe aard, maar dat dit juis hierdie metastorie se performatiewe aard is wat deur die kennis ingespan word om dit te legitimeer (sien "Pragmatique du savoir narratif," hoofstuk 6).

Lyotard wys twee groot legitimeringsverhale uit: dié van die ontwikkeling van die gees en dié van die emansipasie van die mensdom. Wanneer hy dit sê, moet ons onthou dat Lyotard se werk toegespits is op die akademiese praktyk. Maar in wat volg gaan ek "metaverhaal" in 'n breër sin gebruik om ook van toepassing te wees op politieke, kerklike, persoonlike, en ander optrede. Ek sou dalk ook daarna kon verwys as legitimeringsverhale, wat in 'n sosiale raamwerk gesetel is. Metaverhale verloor geloofwaardigheid, deels omdat wetenskap 'n eie lewe kry - weens kommersialisering van inligting, wat 'n instrument in ekonomiese magstryde word.

Om te sien hoe die uiterlike vorme van hierdie metanarratief werk, word die samelewing as 'n geheel (ensemble) van taalspele gesien; die verskillende maniere waarop taal werk, word verduidelik met behulp van die later Wittgenstein se idee van taalspele. Die regverdige opsie vir metaverhale is om 'n veelheid van onversoenbare taalspele, waarin die partikulariteit van elkeen behoue bly, te beoefen. Kom ons bekyk die taalspel 'n bietjie van naderby. Lyotard merk drie belangrike eienskappe van taalspele op (1979:22-23):

1. Spele het nie hulle reèls in hulle self nie, maar hulle verkry dit deur 'n afspraak/ ooreenkoms tussen die spelers.

2. Sonder die reëls is daar geen spel nie.

3. Elke uitspraak word verstaan as 'n hou/skuif (coup). Spel word dus in die kompeterende sin verstaan.

1. "On voit sur ce cas [c'était le récit des Lumières, où le héros du savoir travaille à une bonne fin éthicopolitique, la paix universelle] qu'en légitimant le savoir par un métarécit, qui implique une philosophie de l'histoire, on est conduit à se questionner sur la validité des institutions qui régissent le lien social: elles aussi demandent à être légitimées. La justice se trouve ainsi référée au grand récit, au même titre que la vérité." (Lyotard 1979:7) 
Hiermee saam word ' $n$ taalspel beskou as ' $n$ moment in 'n meer algemene stryd dié binne die gemeenskap - dit wil sê dat alle uitsprake sukses-gedrewe is. Dit is Lyotard se oortuiging dat waarneembare sosiale bande uit sulke taalskuiwe/-houe opgemaak is. Hierop wil ek die volgende kommentaar lewer:

1. Die kontrak/afspraak wat die spelreëls bepaal, is 'n gebeurtenis in die lewe van die spelers en maak dus deel uit van 'n groter (lewens-/professie- $/$...) verhaal.

2. Verder bestaan daar tipes spel met laaggestruktureerde reëls, naamlik die manier waarop kinders speel. Hierdie vorm van spel is nie kompeterend van aard nie. Gevolglik wantrou ek ' $n$ eensydige beskouing van taal as stryd - taal is veel meer as dit.

Daarom beskou ek ook waarneembare sosiale verhoudings as veel meer omvangryk as stryd en ons moet ook nie vergeet om nie-waarneembare (in die wetenskaplike sin van die woord) sosiale bande in ag te neem nie. Hierdie is 'n beperkte kykie na Lyotard; 'n deeglike studie behoort sy later werke ook te verreken. Dié voorlopige studie bring egter die waardevolle insigte na vore, naamlik:

- dat taal, en daarom verhale, wel soms stryd inhou, maar nie altyd nie;

- dat verhale mense se optrede en taalspele voorafgaan;

- dat ' $n$ taalspel ingebed is in 'n narratief wat aan die reëls daarvan legitimiteit gee - ons ontsnap nie die spel nie;

- $\quad$ dat spreke oor die geldigheid van uitsprake gekoppel is aan ' $n$ begrip van geregtigheid wat in dieselfde asem geformuleer word.

\subsection{Historiese bewussyn en verstaanshorison}

Ons beoefening van ' $n$ bepaalde dissipline veronderstel dus dat daar reeds ' $n$ vorm van legitimasie vir die beoefening daarvan is, en wat deur die beoefening tot uitdrukking kom. Die tipe tekste waarop hierdie studie gerig is, is die tekste waarin die stories van die kerk vertel en/of gelegitimeer word. Soos met alle stories is hulle onderworpe aan die fundamentele gegewens van die mens se verstaanservaring - overgeset synde, hulle poog om ' $n$ verstaan te kenne te gee en om 'n verstaanservaring aan te bied waaruit die leser 
iets kan verneem. Dit bring ons by die laaste blik wat ek wil bied op die leefwêreld van storievertellery, naamlik die verstaanshorison en historiese bewussyn. Ek steun hier op Gadamer.

Elke mens wat wil verstaan, is in 'n situasie. Die situasie is 'n antropologiese gegewe: mens kan nie teenoor die situasie gaan staan om dit soos 'n objek te bekyk nie; dit is die posisie van waaruit daar gekyk word. Horison is die verstaanskorrelaat van die situasie: "Horizont ist der Gesichtskreis, der all das umfaßt und umschließt, was von einem Punkte aus sichtbar ist" (Gadamer [1960] 1975:286). Die verstaanshorison van 'n mens is die kontingente historiese situasie wat die vertrekpunt is van waaruit die wêreld bevra word en van waaruit ' $n$ mens leef.

Maar die verstaanshorison bring altyd reeds 'n historiese bewussyn saam. Die bewussyn is geworpe in 'n stroom van uitwerkings wat aan ons opgedring word namate ons in 'n situasie ingelei word. Hierdie Wirkungsgeschichte rig ons aandag (dit wys byvoorbeeld die geskikte vrae in ons situasie uit) en is altyd (bewustelik of onbewustelik) in ons aan die werk. Dit is die horison van die geskiedenis en ons ontmoet dit/kom dit tegemoet in die tradisie. Die bewussyn, wat onder die invloed van die gesitueerdheid in die beweging van geskiedenis staan, noem Gadamer die Wirkungsgeschichtliche Bewußtsein. Dié bewussyn sien altyd die hede saam met die geskiedenis, net soos die verstaanshorison altyd die verlede in die agterkop het. So is verlede en hede altyd in ' $n$ mens in gesprek. Die horison van die tradisie en dié van die verstaner is egter nie twee sake wat apart, op hulle eie bestaan nie. Verstaan (wat die verhouding waarin die verstaner en wat te verstane gegee word, stig en voortsit) is die versmelting van hierdie twee aspekte van 'n mens se bewussyn - die historiese en die huidige horisonne. ${ }^{2}$

Die horisonsversmelting behels egter nie die totale opheffing van die twee onderskeie horisonne nie. Die spanning tussen die historiese horison en die horison van die verstaner in die hede, konstitueer die hermeneutiese probleem. En dit is die taak van die Wirkungsgeschichtliche Bewußtsein om die gekontroleerde voltrekking van die versmelting van horisonne te behartig. Gadamer beskou as die sentrale probleem van die hermeneutiek die probleem van die verhouding tussen die onderskeid van horisonne en hulle

2. "Der Horizont der Gegenwart bildet sich also gar nicht ohne die Vergangenheit. Es gibt sowenig einen Gegenwartshorizont fur sich, wie es historische Horizonte gibt, die man zu gewinnen hătte [sien Gadamer 1975 [1960]:283]. Vielmehr ist Verstehen immer der Vorgang der Verschmelzung solcher vermeintlich für sich seiender Horizonte" (Gadamer [1960] 1975:289). 
eenheid in versmelting (Gadamer [1960] 1975:290, 298), of ek kan ook sê, tussen die tradisie wat algemeen op mense inwerk en die partikuliere verstaan van die indiwidu in sy of haar konteks. Die wyse waarop Gadamer hierdie saak konseptualiseer, is in terme van toepassing (Anwendung).

Gadamer se konsepsie van toepassing is gevorm deur Aristoteles se idee van fronesis, wat laasgenoemde in die Nichomachiese Etiek uitwerk. Ons weet dat Aristoteles hom rig teen Sokrates se bekende beskouing, "kennis is deug" en teen Plato se soortgelyke beskouing dat deug 'n besondere toepassing van 'n algemene, vooraf verworwe teoretiese insig is. Aristoteles, daarenteen, sien etiese kennis as praktiese of toegepaste kennis. ${ }^{3}$ Hierdie verstaan-deur-optrede verskil van dié van tegniese kennis:

- By tegniese kennis bly die algemene kennis min of meer dieselfde en die vraag is hoe om dit die beste toe te pas. Etiese kennis vereis só 'n praktiese toepassing, dat die algemene kennis van die deug pas deur die beoefening daarvan geken kan word. ${ }^{4}$

- Tegniese kennis is ' $n$ middel om 'n spesifieke doel mee te bereik. Etiese kennis is ook die middel om die doel van 'n goeie lewe te bereik, maar dit is eers deur die keuse van wat gedoen moet word om dit te bereik, dat 'n prentjie van wat die goeie lewe is, kristaliseer.

- Tegniese kennis word nie in hierdie mate deur die beoefening daarvan verander nie, terwyl etiese kennis 'n wisselwerking vereis tussen die algemene begrip van norme en 'n openheid vir die besondere eise van 'n spesifieke situasie.

Gadamer se gevolgtrekking is dat Aristoteles se konsepsie van etiese kennis (fronesis) as model dien, waardeur die onlosmaaklike verhouding tussen verstaan, uitleg

3. "Denn da sittliche Wissen, wie es Aristoteles beschreibt, ist offenkundig kein gegenstăndliches Wissen, d.h. der Wissende steht nicht einem sachverhalt gegenuber, den er nur feststellt, sondern er ist von dem, was er erkennt, unmittelbar betroffen. Es ist etwas, was er zu tun hat" (Gadamer [1960] 1975:297).

4. Dit kom veral goed na vore in Aristoteles se konsepsie van natuurreg. Etiese begrippe "... sind also nicht Normen die in den Sternen stehen oder in einer sittlichen Naturwelt ihren unverănderlichen Ort haben, so daß es sie nur zu gewahren gibt. Sie sind aber auf der anderen Seite keine bloßen Konventionen, sondern sie geben wirklich die Natur der Sache wieder, nur daB diese sich durch die Anwendung, die das sittliche Bewußtsein von ihnen macht, jeweils erst selber bestimmt" (Gadamer [1960] 1975:303-4). 
en toepassing in die verstaansgebeure begryp kan word. Toepassing bestaan in die besondere konkretisering van die algemene (die tradisie) gedurende die verstaansgebeure in 'n partikuliere situasie.

Dit lyk of Gadamer se beeld van die indiwidu se verstaan eerder beteken dat verstaan iets is wat met ' $n$ mens gebeur as dat dit iets is wat 'n mens doen - neem byvoorbeeld sy pessimistiese slotsom:

In Wahrheit gehört die Geschichte nicht uns, sondern, wir gehören ihr. Lange bevor wir uns in der Ruckbesinnung selber verstehen, verstehen wir uns auf selbstverständliche Weise in Familie, Gesellschaft und Staat, in denen wir leben. Der Fokus der Subjektivităt ist ein Zerrspiegel. Die Selbstbesinnung des Individuums ist nur ein Flackern im geschlossenen Stromkreis des geschichtlichen Lebens. Darum sind die Vorurteile des einzelnen weit mehr als seine Urteile die geschichtliche Wirklichkeit seines seins.

(Gadamer [1960] 1975:261)

Miskien oorspeel Gadamer sy hand - let wel dat hy hierdie opmerking uit persoonlike ervaring maak. Dit weerspieël 'n baie pessimistiese beeld van die moontlikheid van die mens om hom- of haarself uit 'n bepaalde werklikheidsbeskouing te kan lig. Ek deel die kritiek dat sy hermeneutiek op 'n konserwatiewe werklikheidsbenadering kan uitloop. Gadamer laat ons met ernstige probleme vir etiese aanspreeklikheid. Die outonomie van die etiese subjek is egter so 'n omstrede aangeleentheid dat ek nie hiermee die saak as afgehandel beskou nie - ek gee dit deur vir verdere studie.

\section{STORIES EN MENSE}

Ek laat dit oop vir bespreking of bogenoemde vier taamlik wyd uiteenlopende perspektiewe so gemaklik met mekaar in verband gebring kan word. Ek hanteer hulle as vier gelyktydig geldige perspektiewe, wat ek inspan as deel van my beskouing oor verhale. Dit kan ek soos volg saamvat:

Van Lyotard kry ons die perspektief op die dokumente van 'n gemeenskap, naamlik dat hulle voorafgegaan word deur legitimeringsverhale, wat ook as performa- 
tiewe uitsprake in die dokumente aanwesig is. Dit kan groot verhale of klein verhale (soos in Habermas en Rorty se konsensus-modelle) wees. Van Kuhn het ons die beeld van die verskeidenheid paradigmas waaraan 'n persoon behoort - elkeen die gemeenskaplike besit van die spesifieke paradigma(s) se gemeenskap - 'n samebinding van simbole, lojaliteite en metafisiese beskouings en heuristiese modelle - maar wat tog verskillende toepassings tolereer - toepassings wat die effek is van ander lojaliteite, ensovoorts. Van Gadamer het ons die perspektief van 'n sterk historiese stroom waardeur 'n skrywer/verteller meegesleur word, maar weereens in die heen-en-weer tussen wat verstaan moet word en die verstaner - die hermeneutiese spiraal - iets van die verstaner se eie toepassing van die tradisie kristaliseer. Ons stories skep ons, maar ons skep ook ons geskiedenis/stories. En in dit alles werk Jeismann se drie funksies van verhale/ geskiedenis in die hede: verhale legitimeer aansprake of optrede, dit stig identiteit, en verhale bewerk lewensoriëntasie.

Elke mens het 'n lewensverhaal. Hierdie verhaal verwys voortdurend na ander mense se verhale, waaraan dit ook deelneem. So neem groepsverhale vorm aan wat gemeenskaplike besit is, maar verskillend toepassing vind. Elke mens speel mee in verskillende groepe en hulle verhale, maar alle mense is nie ewe vertroud met hierdie verhale nie, daarom kan almal nie dieselfde tussenverhalige ooreenkomste, aanspelings en resonansies opmerk en daarop reageer nie. Mens se selfverstaan word verhaalmatig uitgeleef en deur stories verwoord. Daar word ook probeer om ander dinge as ' $n$ mens se identiteit te verklaar - die legitimiteit van hierdie verklarings is afhanklik van die wyse waarop dit in 'n gemeenskap se verhale plek kry. Oor die algemeen (soos nou reeds bekend) vervul verhale drie funksies: dit legitimeer optrede of ander verhale, dit stig identiteit, en dit oriënteer lewens. Dit oriënteer dus ook die verstaan van alles rondom mense - soos die Wirkungsgeschichte rig dit ons ondervraging van die wêreld. Soms stry verhale om dominansie (soos by paradigmas of konflikterende metanarratiewe). Soms resoneer hulle met mekaar. Andersins werk hulle ongesiens, sonder dat ons altyd van hulle bewus kan wees; hulle werking is nie altyd deursigtig nie. Maar uit hulle kan ons nie kom nie. Dit is ' $n$ antropologiese gegewe. Ons is in stories gewerp en moet hulle verder uitspeel/ontwerp. Alle stories is uiteindelik ingebed in persoonlike en sosiale lewe - laasgenoemde is die oord van die wil tot mag, van libido, van ekonomiese en ander 
belange, van ons verhouding teenoor mekaar en etiese verantwoordelikheid. Maar dit is ook die oord van vrese en verlangens, angste, hoop, begeertes, teleurstellings, aspirasies, liefde, geloof - dinge wat deel van 'n mens se lewensverhaal uitmaak, vorm daaraan gee, maar nie noodwendig verwoord kan word nie. Dit kan wel in stories, in die manier waarop hulle geleef en vertel word, manifesteer. In ander gevalle is dit die eksplisiete onderwerp van stories. Daar is egter nie 'n een-tot-een-duiding tussen 'n storie en die leefwêreld waaruit dit groei nie. Stories word in verband gebring met die verlede en vooruit geprojekteer in die toekoms ter wille van hoop. 'n Bepaalde mate van kontinuïteit (selfs al sal dit eers later ingesien kan word) is nodig vir die ervaring van sinvolheid van die storie. In die mate waarin die inneem van 'n kritiese distansie tot verhale moontlik is, kan dit lei tot disoriëntasie en heroriëntasie.

\section{TWEE ELEMENTE VAN 'N SELFKRITIEK IN DIE SUID- AFRIKAANSE KONTEKS}

Tot hiertoe het ek 'n perspektief voorgestel van waaruit (kerklike) dokumente en die verhouding tussen sulke dokumente en hulle persoonlike en sosiale omgewing verstaan kan word. As ons tot sover gekom het, kan ek nou twee ander sake uiteensit wat ek reken waardevol kan wees vir iemand wat die kerk aan 'n kultuurkritiese selfbekyking wou blootstel. Ek beoog om 'n betekenisvolle verstaan van wat rassisme is en enkele momente in die politieke ontwikkeling van Suid-Afrika in die laaste eeu of so uiteen te sit. Ek is daarvan oortuig dat enige gemeenskap in Suid-Afrika die verhouding waarin dit ten opsigte van nasionalisme en rassisme staan, moet kan verantwoord. Die sosiale milieu waarin ons werk, vereis dat ons ons verhouding tot hierdie sake in die openbaar sal verstaanbaar maak, sodat daar ook kritiese gesprek daaroor gevoer kan word.

\subsection{Afrikaner-nasionalisme}

Wanneer 'n mens na dokumente van 'n gemeenskap in die Suid-Afikaanse konteks wil kyk, is een van die belangrikste groepe verhale/metaverhale waarmee dit in verband staan, dié van die Afrikaner-nasionalisme. Dit is onder andere oor die kerk se verhouding tot Afrikaner-nasionalisme en die manier waarop laasgenoemde aan mense se lewens 
probeer vorm gee en invloed uitoefen op hulle stories, dat die kerk homself moet verantwoord. Dit is 'n omvattende en invloedryke verskynsel, waarvan ek net 'n skets wil gee.

Dit is belangrik om te onthou dat Afrikaner-nasionalisme nie 'n enkelvoudige verskynsel is nie. Daar is twee groot stories, wat met hierdie naam benoem word:

\begin{abstract}
Afrikaner-nasionalisme in die ruimer sin verwys na die sisteem van idees waarvolgens die Afrikaner homself oor 'n lang tydperk verstaan het in situasies wat as sentrale voorbeelde van 'n groepsbewussyn onder Afrikaners geïnterpreteer kan word [sien veral Degenaar 1987:232-233 vir voorbeelde]. In die enger sin, slaan Afrikaner-nasionalisme op ' $n$ ideologiese beweging wat aan die begin van die 20 e eeu ontstaan het en verband hou met 'n verskeidenheid faktore soos die gemeenskaplike herinnering van die Afrikaner se geskiedenis, maar dan binne die ekonomiese en institusionele konteks van daardie tyd.
\end{abstract}

(Degenaar 1987:233)

Hoewel dit dus ten nouste te make het met die Afrikaner, gaan ek nie nou aan die tameletjie kou om die Afrikaner te definieer nie, maar dit is belangrik om vereers te onthou dat die Hervormde Kerk 'n volkskerk vir/van[?] die Afrikaner is en dat die meeste skrywers van die kerk se dokumente hulle per handtekening aan die Afrikanervolk verbind (ek verwys na die ondertekening van die kerkwet/-orde). Uit my verdere bespreking behoort dit te blyk dat tensy 'n skrywer eksplisiet sy of haar? verhouding tot die Afrikaner anders uiteensit, dit as vanselfsprekend beskou sou kon word dat so 'n persoon ten minste met Afrikaner-nasionalisme in die ruimer sin identifiseer, en waar-

5. Ter wille van volledigheid en verstaanbaarheid haal ek Degenaar se definisies van die sentrale konsepte aan: Vir die doel van sy bespreking word "... die Afrikaner gedefinieer as 'n wit Suid-Afrikaner wie se moedertaal Afrikaans is. (Voor die 20e eeu moet ons eintlik praat van Hollandse Afrikaners en onthou dat blankheid eers in die 20 e eeu 'n kwalifikasie geword het). Nasionalisme is ' $n$ ideologie waarvolgens prioriteit gegee word aan 'n groep mense se strewe na politieke selfbeskikking, met die gevolg dat die hoogste politieke lojaliteit van die burger uiteindelik aan die nasie toekom. Afrikaner-nasionalisme is bogenoemde ideologie soos toegepas op die Afrikaner; eerstens: in 'n ruim sin, as so 'n sisteem van idees wat oor ' $n$ lang tydperk ontstaan het, en tweedens: in 'n enger sin, as 'n sisteem van idees wat met politieke, sosiale en ekonomiese ontwikkelings in die eerste helfte van die $20 \mathrm{e}$ eeu verband hou. 'n Ideologie is 'n handeling-gerigte sisteem van idees wat bewustelik en onbewustelik funksioneer op die wyse waarop 'n groep mense hul ervaring verstaan, hul politieke gedrag reguleer en hul belange beskerm." (1987:234) 
skynlik ook met Afrikaner-nasionalisme in die enger sin. Kom ons kyk dan gou na hierdie verskynsels.

Geleidelik vanaf die einde van die $18 \mathrm{e}$ eeu word 'n paar groepe mense in SuidAfrika bewus van 'n eie groepsbestaan en -identiteit. Hierdie ontwikkeling is onder andere die gevolg van teëspoed wat beleef is. ${ }^{6}$ Maar dit is belangrik om daarop te let dat die eenheid van die verskillende verhale eers van, sê nou maar, die 1870s af begin maak is. Daar is begin om ' $n$ verenigde geskiedenis te skryf' wat bygedra het tot ' $n$ historiese bewussyn. Die hand van God word agter sekere van die gebeure raakgesien. Daar ontstaan geleidelik 'n bewuswording van uitverkorenheid en geroepenheid, en die geskiedenis word gebruik om nasionalisme te bevorder (Degenaar 1987:238).

Die verband tussen die godsdienstige en politieke oortuigings van die Afrikaner, en die invloed wat dit op die Afrikaner se identiteitsontwikkeling en optrede gehad het, is 'n ingewikkelde historiese aangeleentheid. David Bosch argumenteer téén die "Calvinistiese paradigma" as verklaringsmodel om twee redes:

- “... Afrikaners of the 18th and early 19th centuries were, at most, Calvinists only in the cultural sense and ... very few of them really lived according to the central tenets of the Calvinist faith" (Bosch 1984:18).

- “... just as Afrikaner nationalism was a reaction to the challenge of British imperialism in South Africa ... it may be said, in some sense, the Afrikaner's sense of mission and of being a chosen people - which became prominent from the 1870s onward - developed in response to the British notions of calling and mission" (Bosch 1984:20).

Bosch bied hierop 'n alternatiewe verklaring vanuit drie rigtings se invloed: piëtisme, Calvinisme à la Groen van Prinsterer en Abraham Kuyper en nieu-Fichteaanse Romantiek. Ongelukkig, lyk dit vir my, val sy fokus op die ontwikkelings in die NGK. Dit is algemene kennis dat die NGK se verhouding tot veral geïnstitusionaliseerde

6. Ek praat van voorvalle soos die onafhanklikverklaring van die Graaff-Reinet- en Swellendamse distrikte, die Grensoorloe, die Groot Trek, die anneksasie van Natal, twee vryheidsoorloe, die moleste op die myne, ensovoorts.

7. S J du Toit: Die geskiedenis van ons land in die taal van ons volk - sien Degenaar 1987:236. 
Afrikaner-nasionalisme anders beoefen en verwoord is as in die geval van die NHK. Maar ons kan in gedagte hou dat daar nie waterdigte skeidings in die Afrikanerdom tussen die gedagtewêrelde van die NGK en NHK bestaan het nie (en dat die denke van die NHK se trekker-vaders nie noodwendig so hervormd was nie - let byvoorbeeld op die invloed van Wilhelmus à Brakel). Daarom noem ek die invloed van die drie rigtings as moontlike invloede:

- Die piëtisme se dualistiese werklikheidsbeskouing kan 'n leefstyl ondersteun waar al die aandag aan vroomheid op geestelike gebied gegee word en die morele verantwoordelikheid teenoor ander mense afskeep.

- Van Prinsterer se missionêre leuse: "In isolasie lê ons krag", wat bedoel was om sending na binne, in die Nederlandse samelewing te rig, word hier ter plaatse hervertolk as isolasie ter wille van oorlewing. Bosch sonder $\mathbf{S} \mathbf{J}$ du Toit (wat sy afhanklikheid van Kuyper erken het) uit as iemand wat gehelp het om die parallelle tussen die Afrikaner en Israel van ouds te trek. Hierdie verband is heel algemeen gelê.

- Die nieu-Fichteaanse Romantiek, wat deur Afrikaanse studente in Duitsland (o a Diederichs en Verwoerd) veral in die 1930s opgedoen is, stel die idee van 'n metafisiese basis vir etniese suiwerheid bekend.

Hierdie invloede sou veral sterk invloed kon hê omdat die kerke se identifisering met die Afrikaner se lot geleidelik vorm gegee het aan 'n burgerlike godsdiens, wat tot 'n hoogtepunt kom in die 1950s (aldus Bosch), en word geleidelik deur 'n vorm van pragmatisme verbygesteek.

Hoe dit ook al sy, die Afrikaners se verhaal van die verkryging van selfbeskikking het dus 'n spesifieke vorm van nasionalisme meegebring, naamlik volksnasionalisme.

Volksnasionalisme is ' $\mathrm{n}$ vorm van nasionalisme waarin die groep mense wat die hoogste politieke lojaliteit aan die nasie (nasionale staat) laat toekom, hulself sien as 'n volk met kulturele eienskappe wat eksklusief is ten opsigte van ander volke. Volgens volksnasionalisme moet die nasionale staat 'n 
politieke organisasie wees, gegrond op 'n kultuur-homogene groep mense. So

'n vorm van nasionalisme lei onvermydelik tot 'n politisering van die volks-

kultuur.

(Degenaar 1987:239; my kursivering)

Dit was dan ook wat in Afrikanergeledere, veral vanaf die 1920 s gebeur het. In 'n poging om probleme soos die armblankevraagstuk, die gaping tussen klasse in die Afrikanerdom en gebrekkige selfrespek die hoof te bied, met ander woorde om die politiese, sosiale, ekonomiese en kulturele posisie van die Afrikaners te konsolideer, is onder meer geskiedenis aangewend. In hierdie gees word volksmites ${ }^{8}$ en -helde geskep, waardeur die sentimente van die uniekheid en uitverkorenheid van die volk versterk is en dit word deur godsdienstige taalgebruik verder gelegitimeer. Hierdie tipe sentimente word deur die Afrikaner-elite verwoord en die res van die volk word daaragter gemobiliseer deur byvoorbeeld die herdenkingsfees van die Groot Trek en deur die werking van geheime organisasies en hulle bondgenote. Uiteindelik word volksnasionalisme ook as die regverdiging agter die beleid van afsonderlike ontwikkeling gebruik.

Die beleid van afsonderlike ontwikkeling en die manier waarop dit geïmplementeer is, kom hoe langer hoe meer onder druk, van binne en buite die land. As reaksie hierteen vind ' $n$ belangrike ontwikkeling in die identiteitskonsepsie van die Afrikanervolksnasionalisme plaas. Hermann Giliomee verwoord die ontwikkeling as volg:

Die Afrikaner word gesien as 'n lid van 'n (blanke) bevolkingsgroep wat al hoe meer deel word van 'n (blanke) Suid-Afrikaanse nasie saam met ander blanke etniese groepe. Hierdie blanke identiteit word versterk deur die bevoorregte posisie wat die Afrikaner deel met ander blankes. Ten einde hom in hierdie bevoorregte posisie in te grawe, is die hulp van ander blankes nodig en gevolglik is daar 'n verskuiwing van etniese identifikasie tot rasseidentifikasie.

(aangehaal in Degenaar 1987:248)

8. Degenaar (1987:240-241) noem as voorbeelde die Slagtersnek-voorval, die Groot Trek en die Slag van Bloedrivier. ' $n$ Mens sou die lys kon aanvul met die Paardekraal-gelofte, die Tweede Vryheidsoorlog en ander. 
Oor die strukture waardeur die volksnasionalisme en later al hoe meer die rassenasionalisme in plek gehou is, gaan ek nie nou uitbrei nie.

Ek vertolk bogenoemde ontwikkelinge as 'n klemverskuiwing wat geleidelik intree van ' $n$ Afrikaner-nasionalisme in die ruimer sin (as 'n min of meer legitieme strewe na selfbeskikking) na Afrikaner-nasionalisme in die enger, ideologiese sin - ten koste van ander groepe in die plurale Suid-Afrikaanse samelewing. Die verskuiwing gaan gepaard met 'n verandering in die volkskonsepsie - van simbool van trots en emansipasie na 'n simbool van onderdrukking; “... die beklemtoning van die volksbegrip ... lei tot 'n onderwaardering van die indiwidu en 'n uitskakeling van ander volke in 'n plurale samelewing" (Degenaar 1987:256). Die beklemtoning van ras en die groeiende pragmatisme onder Afrikaners, werk mee tot ekonomiese magsmisbruik deur die blanke Suid-Afrikaanse nasie - met geweldige gevolge.

Die saak van ras-nasionalisme bring ons dan by die volgende vraag uit.

\subsection{Wat is rassisme?}

In my beantwoording van hierdie vraag steun ek op die werk van Albert Memmi (1994), wat ek effens vir my doeleindes aanpas. Dit sal onsinnig wees en ook gevaatlik om oor rassisme te praat sonder om te weet wat daarmee bedoel word.

Dit is natuurlik so dat niemand hom of haarself ' $n$ rassis noem nie. Dit wat ons rassisme noem word by mense aangetref in die vorm van iets wat meestal aangebied word as 'n samehangende en sistematiese teorie. Daar bestaan twee hoof-variante in die teorie: (1) rassisme in die streng sin van die woord, dit is, rassisme wat sentreer om 'n oortuiging van die betekenis van biologiese verskille tussen mense, en (2) rassisme in die breër sin, dit is, rassisme met 'n vergelykbare gesindheid as eersgenoemde, maar wat sentreer rondom ander verskille (Memmi 1994:107). Maar aangesien hulle op vergelykbare wyses manifesteer, kan hulle saam beskryf word.

Die kenmerkende struktuur van rassistiese argumentasie (punte 1-3), saam met die weerlegging daarvan, kan in die volgende punte saamgevat word (Memmi 1994:21-34):

1. Die oortuiging dat daar suiwer, onderskeie rasse bestaan. Hierdie standpunt is biologies onhoudbaar - wat wel die geval is, is dat daar binne 'n spesifieke sosiale 
groep 'n tendens tot bepaalde biologiese karaktertrekke kan voorkom, wat verteenwoordigend is van slegs 'n gedeelte van die kontinue spektrum van vermenging tussen mense. Met ander woorde die biologiese verskille tussen mense word nie ontken nie; wat wel ontken word, is dat 'n sosiale groep met 'n besliste lys van biologiese eienskappe saamval, of andersom gesê, mense wat min of meer dieselfde biologiese eienskappe het, vorm nie noodwendig 'n sosiale groep nie.

2. 'n Waardeoordeel en hiërargisering van die suiwer groepe se eienskappe word gemaak - in die geval van rassisme in die streng sin van die woord, word dit eers volgens die biologiese eienskappe gedoen aan die hand waarvan ander verskille verklaar en ook gehiërargiseer word. In die breër sin word die hiërargisering gemaak op grond van ander eienskappe - sosiale, geestelike, kulturele, intellektuele en ander vorme van meerderwaardigheid - wat met die biologiese kontoere/ skeidslyne saamval. Maar aangesien die eerste standpunt onhoudbaar is, is hierdie deel van die argument ook problematies. Kan superioriteit volgens rassekontoere gehiërargiseer word as daar nie homogene groepe is nie? Daarbenewens is daar geen bewys dat ander vorme van meerderwaardigheid rassekontoere sou volg nie.

Visker (1993:107) argumenteer dat hierdie klassieke vorm van rassisme wat op die hiërargisering van verskille gebaseer is, ook 'n ander vorm aanneem, naamlik die multikulturalistiese standpunt, wat die verskille tussen groepe verabsoluteer in die naam van respek vir die andersheid van die ander. 'n Mens moet sulke gedaante-wisselings in ag neem, maar versigtig bly om nie 'n knap vorm van inkwisisie tegnologie te ontwikkel nie - ek vermoed dat Visker effens vinnig is om die woord rassisme te gebruik.

3. Die hiërargie van eienskappe (of dan ook die verabsolutering daarvan) dien as verduideliking en/of legitimering vir bepaalde regte en/of voorregte. Dit is dus in stryd met die beginsel van meriete/verdienste. 'n Mens kan dus die probleem in die rassistiese argumentasie soos volg opsom: 
[D]aar bestaan beswaarlik iets soos suiwer rasse en net so min biologies homo-gene groepe. As daar so iets sou bestaan, dan sou sulke groepe nie biologies verhewe wees nie. As hulle biologies verhewe sou wees, dan sou hulle nie noodwendig meer begaafd en ook nie kultureel beter ontwikkel wees nie. As dit tog die geval was, dan sou sulke groepe nogtans nie 'n onaantasbare reg hê om meer te eet, beter behuising te hê en onder beter omstandighede te reis nie.

(Memmi 1994:34) ${ }^{9}$

Tot sover oor die rassistiese argument.

Wat vorm betref, toon rassisme sigself dus as 'n pseudo-teorie, waarmee die persoon wat hom of haar van die argumentasie behelp sy of haar integriteit probeer beskerm deur 'n meganisme van uitsluiting te regverdig, tot voordeel van die argumenteerder. Die woord pseudo-teorie word gebruik omdat:

- die argumentasie onder andere spruit uit werklike lewenservaring, maar (1) dit word op 'n onverantwoordbare manier veralgemeen om alle mense in te sluit wat karaktertrekke deel met die persoon van die ervaring en (2) dit word verabsoluteer tot alle tye en plekke. Dit gebeur dan ook dat die verskille tussen die ons-groep en die hulle-groep gesien word as 'n substratum wat die wese van die ander onderlê - kennis van een verskil roep kennis van verdere verskille op. Hierdie veralgemeningstendens lei soms daartoe dat die verskille gesubstantiveer word en selfs verwoord word in metafisiese of teologiese terme. Uiteindelik neig rassisme tot mitevorming (sien Memmi 1994:188). Ek sou dus kon sê dat rassisme 'n tipe metaverhaal is;

- deel van die verklaring van die verskynsel van rassisme te vinde is in die lewe van die persoon wat dit beoefen. Rassisme is gewortel in vrees, wat uitgewoed word in wisselwerking met agressie, en rassisme tree in hierdie stryd op as meganisme tot selfbevestiging/-handhawing (Memmi 1994:110). Hoewel rassisme in die

9. “.. il n'y a guère de races pures, ni de groupes biologiquement homogènes. $Y$ en aurait-il, qu'ils ne seraient pas biologiquement supériers. Seraient-ils biologiquement superieurs, ils ne seraient pas nécessairement surdoués, ni culturellement plus avancés. Le seraient-ils, qu'ils n'auraient pas un droit imprescriptible de manger plus, d'être mieux logés et de voyager dans des meilleures conditions" (Memmi 1994:34). 
emosies van die indiwidu gewortel is, word dit sosiaal verwoord, dit is 'n kultuurproduk wat vir elke mens vanuit 'n arsenaal van kultuurprodukte beskikbaar is om sekere probleme te hanteer: "Rassisme is 'n kollektiewe taal wat ten dienste staan van elkeen se emosies" (Memmi 1994:124-5) ${ }^{10}$. Dit vertoon dus ook karaktertrekke van 'n paradigma en word as deel van 'n verstaanstradisie ontgin.

Ten slotte moet ek daarop wys dat, veral as ons rassisme in verband bring met die debat multikulturalisme/transkulturalisme moet ons in gedagte hou dat die filosofiese probleem oneindig groter is as wat ek hier kan laat blyk. In die lyn van Visker wil ek die debat oor integrasie/segregasie (wat veral in die stryd van die NHK met die WRK lê) sien as deel van die groot debat in Westerse denke oor relatiwisme/universalisme of aspekte van die debat Verligting/Romantiek, ensovoorts (sien Visker 1993:6 en 1999:65).

\section{TEN SLOTTE}

Nadenke oor kritiese selfrefleksie (soos ek in hierbo probeer doen het) wat nie opgevolg word juis deur daardie kritiese selfrefleksie nie, is so onsinnig en nutteloos soos ' $n$ inleiding sonder 'n opstel. En dit is waar, ook van van my artikel: solank as wat dit wat hier geskryf is, geamputeer bly van dit wat daarop moet volg, bly dit 'n oproep tot die Hervormde Kerk om grootmoedigheid aan die dag te lê en om krities na sy verlede en hede te gaan kyk. Vir solank as wat hierdie artikel 'n inleiding sonder 'n opstel bly, bly dit ' $n$ aanklag teen mense wat in die knusheid van anonimiteit en die gemak van gevestigdheid wegkruip vir die kompromislose omgang met die geskiedenis en hede van die kerk, vir die konfrontasie van openbare, akademiese debatvoering. S P Engelbrecht het lank te vore al die kerk op die onontkombaarheid van hierdie taak gewys:

... die verhouding van die Europeaan, die Jood, die Asiaat en die Swarte is 'n vraagstuk wat die nageslag nog sal verontrus. Vandag is ons gerus, want die Europeaan het die oorwig en is aan bewind van sake. Maar sal dit altyd so bly? Die toekoms is in Gods hand, Hy oordeel regverdig, en sy oordele sal oor ons as Europeane kom, as ons nie die regte weg inslaan nie. In menslike

10. "Le racisme est un langage collective au service des émotions de chacun" (Memmi 1994:125). 
taal uitgedruk: Die Blanke ras in Suid-Afrika kan die skepper wees van sy eie ondergang.

(Engelbrecht 1929:4)

\section{Literatuurverwysings}

Bosch, D J 1984. The roots and fruits of the Afrikaner civil religion, in Hofmeyr, J W \& Vorster, W S (eds), New faces of Africa: Essays in honour of Ben Marais. Pretoria: UNISA.

Bosman, H C 1984. Mafeking Road. Cape Town: Human \& Rousseau.

Degenaar, J J 1987. Afrikaner-nasionalisme, in Esterhuyse, W P, Du Toit, P V D P \& Van Niekerk, A A (reds), Moderne Politieke Ideologië̈. Johannesburg: Southern.

Engelbrecht, S P [1929] 1978. Die groot vraagstuk, in Van Wyk, D J C (red), Stemme uit die Verlede: Volkereverhoudings in Suid-Afrika. Pretoria: HAUM.

Gadamer, H-G [1960] 1975. Wahrheit und Methode: Grundzüge einer philosophischen Hermeneutik. Tübingen: Paul Siebeck.

Jeismann, K-E 1985. Geschichte als Horizont der Gegenwart. Paderborn: Ferdinand Schäningh.

Kuhn, T S [1962] 1970. The structure of scientific revolutions. Chicago: University of Chicago Press.

Lyotard, J-F 1979. La Condition Postmoderne: Rapport sur le Savo ' Paris: Minuit.

Memmi, A 1994. Le Racisme: Description, définitions, traitement. ,aint-Amand: Gallimard.

Visker, R 1993. Transculturele Vibrasies. Tmesis 3.

- 1999. Oneuropese verlangens: Op weg na 'n provinsialisme sonder romantiek. Fragmente 3. 